\title{
Konsep Aplikasi E-Pesantren 4.0 di Pondok Pesantren Minhajul Haq Purwakarta
}

Asep Sopian'1, Eko Budi Prasetyo², Muhibbin Syah'3 ${ }^{3}$ Muhammad Erihadiana ${ }^{4}$

1,2,3,4Universitas Islam Negeri Sunan Gunung Djati Bandung, Indonesia

E-mail: sopianasep8793@gmail.com, muhammadnayif1@gmail.com, muhibbinsyah@yahoo.com, erihadiana@uinsgd.ac.id

\begin{abstract}
Article Info
Article History

Received: 2021-10-09

Revised: 2021-11-02

Published: 2021-11-29
\end{abstract}

Keywords:

Information Systems;

Learn;

Boarding school.

\begin{abstract}
Information system is a system that can collect various kinds of information and display it in various media. The Pondok Pesantren Information System application is an information system designed and made specifically to adjust teaching and learning activities at Islamic Boarding Schools which are expected to help the overall activity process. This application is needed to facilitate the collection and management of information generated from the teaching and learning process in one place that is easy to access and redistribute. The research method used in this qualitative approach is the case study method. A research method that aims to describe a particular situation or field in an analytical, factual and systematic manner. The results of this study indicate that the application development process begins with the interview stage to the Minhajul Haq Islamic Boarding School Purwakarta as a research target then to the information system design stage based on the results of interviews and making applications according to the design made, lastly a survey is carried out to determine whether the application is suitable for use in the room. the internal scope of the Minhajul Haq Islamic Boarding School in Purwakarta. With the existence of a digitalbased information system at Islamic boarding schools, boarding school administrators can find out Santri data, payment recaps, curriculum and building data owned by Islamic boarding schools, this is related to technology development in Islamic boarding schools, to realize student data integration.
\end{abstract}

\begin{tabular}{l}
\hline Artikel Info \\
\hline Sejarah Artikel \\
Diterima: 2021-10-09 \\
Direvisi: 2021-11-02 \\
Dipublikasi: 2021-11-29
\end{tabular}

Kata kunci: Sistem Informasi; Belajar;

Pesantren.

\begin{abstract}
Abstrak
Sistem Informasi adalah sebuah sistem yang dapat mengumpulkan berbagai macam informasi dan menampilkannya dalam berbagai media. Aplikasi Sistem Informasi Pondok Pesantren merupakan sebuah sistem informasi yang didesain dan dibuat khusus untuk menyesuaikan kegiatan belajar mengajar pada Pondok Pesantren yang diharapkan dapat membantu proses kegiatan secara keseluruhan. Aplikasi ini dibutuhkan untuk memudahkan dalam pengumpulan dan pengelolaan informasiinformasi yang dihasilkan dari proses belajar mengajar dalam satu tempat yang mudah untuk diakses dan disebarkan kembali. Metode penelitian yang digunakan pada pendekatan kualitatif ini yaitu dengan metode studi kasus. Metode penelitian yang bertujuan untuk mendeskripsikan suatu situasi atau bidang tertentu secara analisis, sistematis faktual dan teliti. Hasil Penelitian ini menunjukkan bahwa proses pengembangan aplikasi dimulai dengan tahap wawancara ke Pondok Pesantren Minhajul Haq Purwakarta sebagai target penelitian kemudian ke tahap perancangan sistem informasi berdasarkan hasil wawancara dan pembuatan aplikasi sesuai rancangan yang dibuat, terakhir dilakukan survey untuk menentukan apakah aplikasi layak untuk digunakan dalam ruang lingkup internal Pondok Pesantren Minhajul Haq Purwakarta. Dengan adanya Sistem Informasi berbasis digital di Pondok Pesantren, pengurus pondok dapat mengetahui data Santri, rekap pembayaran, kurikulum dan data gedung yang dimiliki oleh pondok pesantren, hal ini berkaitan dengan pengembangan teknologi di pondok pesantren, untuk mewujudkan integrasi data santri.
\end{abstract}

\section{PENDAHULUAN}

Pondok pesantren merupakan tempat pendidikan berasaskan Agama Islam, dimana para santrinya di bawah bimbingan seorang ulama, yang lebih dikenal dengan kyai. Dimana pondok pesantren ini lahir ditengah-tengah masyarakat khususnya masyarakat islam. Didirikannya Pondok pesantren bertujuan untuk memberi pelajaran ilmu agama islam kepada para santrinya supaya bisa menjadi bekal untuk dirinya baik di dunia maupun akhirat, tidak sedikit pondok pesantren yang mencoba 
menyesuaikan diri akan suatu perubahan, namun ada juga pondok pesantren yang menutup diri dari pengaruh perkembangan teknologi saat ini.

Pondok pesantren sebagai sebuah sekolah tentunya memiliki berbagai macam informasi yang harus dikelola. Saat ini, informasi-informasi yang berada didalam pondok pesantren secara umum dikelola secara manual. Pengelolaan informasi secara manual ini rentan terhadap kerusakan dan kehilangan. Dibutuhkan sebuah perubahan terkait pengelolaan informasi ini. Menurut (Bairizki, 2021) bahwa perubahan pada proses pengelolan organisasi merupakan bagian dari perbaikan tata kelola organisasi.

Menurut (Mayasari, 2021) bahwa sistem informasi adalah sebuah data yang penting bagi proses penyelenggaran manajemen. Sistem informasi dalam sebuah organisasi dibatasi oleh data yang dapat diperoleh, biaya untuk pengadaan, pengolahan dan penyimpanan dan sebagainya. Menurut (Jogiyanto, 2005) bahwa sebuah sistem informasi berdasarkan komputer biasanya dapat mengurangi biaya sekaligus meningkatkan kemampuan dan prestasi sistem informasi. (Kristanto, 2008), mendefinisikan sistem informasi merupakan kumpulan dari perangkat keras dan perangkat lunak komputer serta perangkat manusia yang akan mengolah data menggunakan perangkat keras dan perangkat lunak tersebut.

Menurut (Supriyanto, 2005) sistem informasi adalah sistem didalam suatu organisasi, yang mempertemukan kebutuhan pengolahan transaksi harian, mendukung operasi bersifat manajerial dan kegiatan strategi dari suatu organisasi dan menyediakan pihak luar tertentu dengan laporan-laporan yang diperlukan, sistem Informasi Manajemen atau SIM, menurut McLeod dan Schell dalam (Arifudin, 2021) adalah suatu sistem berbasis komputer yang membuat informasi tersedia bagi para pengguuna yang memiliki kebutuhan serupa. Dalam pendapat lain, M. Scott dalam (Nasser, 2021) menjelaskan bahwa SIM ini adalah kumpulan sistem yang terkoordinasi dan bersifat rasional. Sistem tersebut bekerja untuk mengolah data menjadi sebuah informasi yang berharga.

Berdasaran berbagai pendapat yang ada ahwa secara umum sistem informasi dapat didefinisikan sebagai berikut : 1) Suatu sistem yang dibuat oleh manusia yang terdiri komponenkomponen dalam organisasi untuk mencapai suatu tujuan yaitu menyajikan informasi, 2) Sekumpulan prosedur organisasi yang pada saat dilaksanakanakan memberikan informasi bagi pengambil keputusan dan atau untuk mengendalikan organisasi, dan 3) Suatu sistem dalam suatu organisasi yang mempertemukan kebutuhan pengolahan transaksi, mendukung operasi, bersifat manajerial dan kegiatan strategi dari suatu organisasi dan menyediakan pihak luar tertentu dengan laporan-laporan yang diperlukan. Dalam dunia pendidikan menurut (Juhji, 2020) bahwa sistem informasi dapat berkontribusi pada penyelenggaraan proses pendidikan yang efektif dan efisien, sistem Informasi adalah kombinasi antara manusia, teknologi informasi dan proses bisnis untuk mencapai suatu tujuan bisnis. Menurut (Irwansyah, 2021) bahwa sistem Informasi dapat dilambangkan dengan segitiga dimana tiap sudutnya melambangkan manusia, proses, dan teknologi informasi. Tiga bagian dari sistem informasi sering disebut "Information Systems Triangle".

Beberapa komponen yang terdapat dalam sebuah sistem informasi, menurut (Al-Fedaghi, 2011) yakni: 1) Komponen input merupakan data yang masuk ke dalam sistem informasi, 2) Komponen model kombinasi prosedur, logika, dan model matematika yang memproses data yang tersimpan di basis data dengan cara yang sudah di tentukan untuk menghasilkan keluaran yang diinginkan, 3) Komponen output menyediakan informasi yang berkualitas dan dokumentasi yang berguna untuk semua tingkatan manajemen serta semua pemakai system, 4) Komponen teknologi merupakan alat dalam sistem informasi, teknologi digunakan untuk menerima input, menjalankan model, menyimpan dan mengakses data, menghasilkan dan mengirimkan output dan memantau pengendalian system, 5) Komponen basis data merupakan kumpulan data yang saling berhubungan yang tersimpan di dalam komputer dengan menggunakan software database, 6) Komponen kontrol adalah pengendalian yang dirancang untuk menanggulangi gangguan terhadap sistem informasi.

Pondok Pesantren Minhajul Haq Purwakarta sebagai salah satu pondok pesantren yang modern seharusnya memiliki sebuah sistem informasi yang dapat mengelola seluruh informasi terkait pondok pesantren secara online untuk mengatasi permasalahan kerusakan dan kehilangan informasi yang telah diolah dan diproses. Sistem informasi juga dibutuhkan sebagai media penyedia informasi-informasi seputar pondok pesantren agar para santri dapat dengan mudah mengakses informasi-informasi 
terbaru dalam satu tempat.

Mengingat akan pesatnya kemajuan teknologi yang sudah merambah kesemua bidang, Serta pola kehidupan masyarakat yang sudah relatif maju, dapat dipastikan hampir semua orang saat ini sudah memanfaatkan teknologi internet sebagai media penyampaian suatu informasi. Untuk mendapatkan informasi yang dibutuhkan, kita tidak perlu membuang waktu dan tenaga untuk datang ke tempat yang memiliki informasi tersebut, melainkan kita dapat memperoleh informasihanya dengan mengakses internet dari manapun dan kapanpun asalkan tersedia layanan internet, dengan adanya internet masyarakat dapat bertukar informasi dengan mudah dan cepat, tanpa harus bertemu di suatu tempat hanya untuk menyampaikan suatu informasi, dengan pengamatan permasalahan diatas, kami membuat "Konsep Aplikasi e-Pesantren di Pondok Pesantren Minhajul Haq Purwakarta".

\section{METODE PENELITIAN}

Penelitian Simple Research Design (SRD) ini menggunkan pendekatan kualitatif. Penggunaan pendekatan ini disesuaikan dengan tujuan pokok penelitian yaitu dalam rangka mengungkap data Konsep Aplikasi e-Pesantren di Pondok Pesantren Minhajul Haq Purwakarta. Menurut (Sugiyono, 2012) bahwa penelitian kualitatif adalah penelitian yang digunakan untuk meneliti pada kondisis objek yang alamiah, di mana peneliti adalah sebagai instrumen kunci". Sedangkan menurut Moleong dalam (Rahayu, 2020) bahwa penelitian kualitatif adalah "tradisi tertentu dalam ilmu pengetahuan sosial yang secara fundamental bergantung dari pengamatan pada manusia baik dalam kawasannya maupun dalam peristilahannya". Penelitian ini dilaksanakan untuk mendeskripsikan dan menganalisis Konsep Aplikasi e-Pesantren di Pondok Pesantren Minhajul Haq Purwakarta. Dengan kata lain bahwa kajian penelitian ini pada hakekatnya mengamati kegiatan manusia dalam lingkungan atau organisasi sehubungan dengan pengelolaan Konsep Aplikasi e-Pesantren di Pondok Pesantren Minhajul Haq Purwakarta.

Metode penelitian yang digunakan pada pendekatan kualitatif ini yaitu dengan metode studi kasus. Metode penelitian yang bertujuan untuk mendeskripsikan suatu situasi atau bidang tertentu secara analisis, sistematis faktual dan teliti. Menurut (Bahri, 2021) mengemukakan bahwa studi kasus adalah "merupakan penelitian yang mencakup pengkajian bertujuan memberikan gambaran secara mendetail mengenai latar belakang, sifat maupun karakter yang ada dari suatu kasus, dengan kata lain bahwa studi kasus memusatkan perhatian pada suatu kasus secara intensif dan rinci". Penelitian dalam metode ini dilakukan secara mendalam terhadap suatu keadaan atau kondisi dengan cara sistematis mulai dari melakukan pengamatan, pengumpulan data, analisis informasi dan pelaporan hasil. Dalam hal ini peneliti lebih banyak berinteraksi dengan subjek penelitian serta mengamati berbagai kegiatan yang ada. Peneliti mengamati berbagai kejadian dan gejala pada kegiatan yang berkaitan dengan Konsep Aplikasi e-Pesantren di Pondok Pesantren Minhajul Haq Purwakarta dalam rangka mengungkap data-data Konsep Aplikasi ePesantren di Pondok Pesantren Minhajul Haq Purwakarta. Suatu kasus menarik untuk diteliti karena corak khas kasus tersebut yang memiliki arti pada orang lain, minimal bagi peneliti, Sumber data dalam penelitian ini adalah subyek dari mana data dapat diperoleh. Suharsimi Arikunto (Arikuntoro, 2006) mengemukakan bahwa sumber data adalah "subjek dari mana data dapat diperoleh". Pada penelitian ini tekhnik pengumpulan datanya menggunakan wawancara, dengan sumber data disebut responden yakni orang yang merespon atau menjawab pertanyaan-pertanyaan peneliti, baik pertanyaan tertulis maupun lisan dalam rangka mengungkap data-data Konsep Aplikasi e-Pesantren di Pondok Pesantren Minhajul Haq Purwakarta. Adapun data-data dalam penelitian ini yakni sebagai berikut : 1) Data Primer adalah sumber data yang langsung memberikan data kepada pengumpul data, dan 2) Data Sekunder adalah sumber data yang diperoleh dengan cara membaca, mempelajari dan memahami melalui media lain yang bersumber dari literatur, buku-buku, serta dokumen.

\section{HASIL DAN PEMBAHASAN}

A. Konsep e-Pesantren 4.0 di Pesantren Minhajul Haq Purwakarta

Konsep e-Pesantren 4.0 menurut (Syafe'i, 2017) adalah konsep digitalisasi yang mengintegrasikan informasi pesantren, santri, dan orangtua dalam satu platform, sehingga membentuk sebuah media pengelolaan data pesantren yang praktis. dengan modul pokok management sistem pondok pesantren, ePesantren 4.0 ini dapat membangun suatu sistem yang dapat mempercepat kinerja staf/pegawai serta mempererat hubungan antara orang tua wali santri dengan pesantren 
yang bersangkutan. Menurut (Nadeak, 2020) bahwa dengan pendekatan manajemen dapat membantu dalam manajemen \& administrasi pesantren. Sehingga pondok pesantren menjadi lebih maju dan professional, adapun sistem informasi e-Pesantren 4.0 yang diterapkan di Pondok Pesantren Minhajul Haq Purwakarta diantaranya sebagai berikut:

1. SISFO (Sistem Informasi) Manajemen Madrasah

Manajemen Madrasah merupakah sistem informasi yang berkaitan dengan Manajemen Madrasah. meliputi Profil, Sejarah, Visi-Misi, Struktur Organisasi, Identitas Guru, Data Santri dan lain sebagainya. Informasi yang berkaitan dengan pesantren dan madrasah dapat di kelola melalui sistem ini pada portal website www.minhajulhaq.or.id

2. SISFO (Sistem Informasi) Manajemen Kepegawaian

Sistem Informasi yang dirancang sebagai solusi untuk menangani berbagai hal dalam pengurusan kepegawaian mulai dari penyimpanan dan pemusatan data secara terkomputerisasi hingga menangani berbagai macam laporan yang berhubungan dengan kepegawaian sehingga memudahkan untuk meningkatkan kebutuhan Administrasi kepegawaian. Sistem Informasi ini sebagai jawaban terhadap Manajemen Kepegawaian untuk memantapkan administrasi Kepegawaian sebagai upaya untuk memenuhi kebutuhan informasi data pegawai yang cepat, tepat, akuntabel, dan up to date, melalui portal www.hris.minhajulhaq.or.id

3. SISFO (Sistem Informasi) Akademik Sistem Informasi Akademik yang dibangun untuk memberikan kemudahan kepada pengguna dalam kegiatan administrasi akademik pesantren secara online. Kegiatan administrasi akademik pesantren seperti; proses Penerimaan Pesrta Didik Baru (PPDB), pembuatan jadwal pelajaran, pengisian RPP, pengisian Silabus, pengisian raport, pengisian nilai, perwalian, pengelolaan data guru \& santri yang dapat digunakan secara online. Sistem ini juga dapat berfungsi sebagai pendukung untuk analisis data dalam menentukan keputusan pesantren Minhajul Haq Purwakarta.
4. SISFO (Sistem Informasi) Manajemen Pembayaran

Manajemen data pembayaran di pesantren sehigga mudah dalam pengambilan keputusan oleh bagian keuangan pesantren. Data pembayaran seperti SPP, Uang Pangkal, Uang Kegiatan Santri Tahunan (UKST), Uang Saku Santri, Infaq, Sedekah, Zakat ataupun Wakaf. sistem ini dapat dikelola dan dikases pada www.app.minhajulhaq.or.id

5. SISFO (Sistem Informasi) Computer Based Test

CBT (Computer Based Test) adalah penggunaan komputer dalam tes dan penilaian hasil belajar siswa/santri. Klasifikasi yang dipakai dalam penilaian hasil belajar ini meliputi penilaian diagnostik, tes individu, dan tes sumatif. Selain itu, CBT juga dapat di implementasikan di pesantren untuk mendorong penyesuaian diri santri dengan perkembangan teknologi dan persiapan studi lanjut.

6. SISFO (Sistem Informasi) Manajemen Tabungan

Sistem informasi yang tujuanya untuk manajemen tabungan masuk dan pengeluaran santri. Sehingga bagian keuangan mudah dalam pengambilan keputusan. Wali santri juga dapat mengetahui saldo tabungan santri sehingga dapat memonitor juga pengeluaran santri. melalui www.app.minhajulhaq.or.id

7. SISFO (Sistem Informasi) Manajemen Konseling

Sistem yang menampilkan informasi mengenai pelanggaran santri di madrasah dan pengasuhan serta informasi penanganan yang diberikan oleh guru pembimbing. Tugas utama dari seorang guru pembimbing (Guru BP/BK) adalah memberikan konsultasi dan bimbingan kepada seluruh santri. Sistem ini membantu mengkoordinasikan antara pihak madrasah, guru/walikelas dan pengasuh, serta orangtua jika terjadi pelanggaran yang dilakukan oleh santri di pesantren.

8. SISFO (Sistem Informasi) Manajemen Monitoring dan Tahfidz Santri

Sistem ini menampilkan monitoring aktivitas dan tahfidz santri setiap hari sehingga wali santri dapat mengetahui 
perkembangan santri setiap saat. Laporan yang berkaitan dengan aktivitas harian, pencapaian, penambahan hafalan dan murojaah harian. Sehingga sistem informasi ini dapat menjadikan bahan pertimbangan pengambilan keputusan oleh bagian yang bersangkutan.

9. SISFO (Sistem Informasi) Manajemen Rekap Medis

Sistem ini menampilkan jejek rekam medis mengenai identitas pasien, pemeriksaan, pengobatan, serta meliputi pencatatan, pelaporan, pengumpulan, pendaftaran, pengisian, dan analisis data terkait kebutuhan informasi untuk mendiagnosa pasien agar mendapatkan penanganan dan perawatan yang tepat. Sistem ini juga akan menampilkan laporan harian santri yang mengalami sakit dan orang tua juga akan mengetahui perkembangan santri mengenai kesehatanya melalui Sisfo Manajemen Rekap medis.

10.SISFO (Sistem Informasi) Broadcast Sistem ini bertujuan untuk membagikan informasi berkaitan dengan kegiatan, agenda, program dan pengumuman kepada orang tua wali santri atau publik yang bersifat internal atau eksternal. Sehingga wali santri dan publik mengetahui apa saja kegiatan yang akan dilaksanakan maupun yang ada di pesantren.

11.SISFO (Sistem Informasi) Perpustakaan Digital

Sistem ini bertujuan untuk pengelolaan data perpustakaan digital meliputi data buku, data peminjaman, data pengembalian, data rak. Perpustakaan digital pesantren juga akan dilengkapi dengan sistem OPAC (Online Public Access Catalog) sehingga mempermudahkan pencarian buku di dalam perpustakaan dan akan menampilkan lokasi buku tersebut. Dan aplikasi perpustakaan ini juga nantinya bisa diakses wali santri dan publik yang ingin membaca koleksi buku di pesantren Minhajul Haq Purwakarta. adapun sistem informasi perpustakaan digital ini dapat diakses atau dikelola pada www.lib2minhajulhaq.or.id untuk perpustakaan putra, www.lib.minhajul-haq.or.id untuk perpustakaan putri.
12.Digital Information System

Sistem ini sifatnya internal pesantren Minhajul Haq Purwakarta yang mana menampilkan informasi bersifat digital. Informasi yang ditampilkan kegiatan, media belajar, media berdakwah, pengumuman, dan lain sebagainya. Selain itu juga dapat menampilkan berbagai informasi pendukung lainya. Hal ini bertujuan dengan adanya Digital Information System semua informasi yang di bagikan dapat secara cepat dan mudah dipahami oleh santri sehingga santri dapat memanajemen waktu mereka masing-masing dengan baik.

B. Manfaat e-Pesantren 4.0 di Pesantren Minhajul Haq Purwakarta

1. Manfaat bagi Pengelola Pesantren

a) Memudahkan segala urusan Administrasi/ Keuangan Pesantren Minhajul Haq Purwakarta.

b) Mempercepat pencatatan kerja, laporan--laporan, rekap dan komunikasi dengan walisantri menjadi lancer

c) Memudahkan dalam broadcast berita dan pengumuman ke walisantri.

d) Meningkatkan kepercayaan walisantri terhadap pesantren Minhajul Haq Purwakarta

e) Mempererat ukhuwah antara pesantren Minhajul Haq Purwakarta dan walisantri.

f) Salah satu bentuk kebaikan madrasah dan pesantren kepada orang tua santri adalah memberi informasi perkembangan santri.

2. Manfaat bagi Orang tua / Wali santri

a) Orang tua dapat mengetahui perkembangan anaknya (SPP, tahfidz, kesehatan, absensi, uang saku, dan lain sebagainya)

b) Sebagai pengurang rasa rindu orang tua yang anaknya menjadi santri di pesantren Minhajul Haq Purwakarta.

c) Menghilangkan kekhawatiran orangtua yang anaknya kehabisan uang jajan di pesantren Minhajul Haq Purwakarta.

d) Mendapatkan update berita/informasi berkaitan dengan madrasah ataupun anaknya 
C. Tim yang terlibat dalam pengembangan ePesantren 4.0

Tim yang terlibat dalam pengembangan aplikasi e-Pesantren 4.0 di Pesantren Minhajul Haq Purwakarta adalah sebagai berikut:

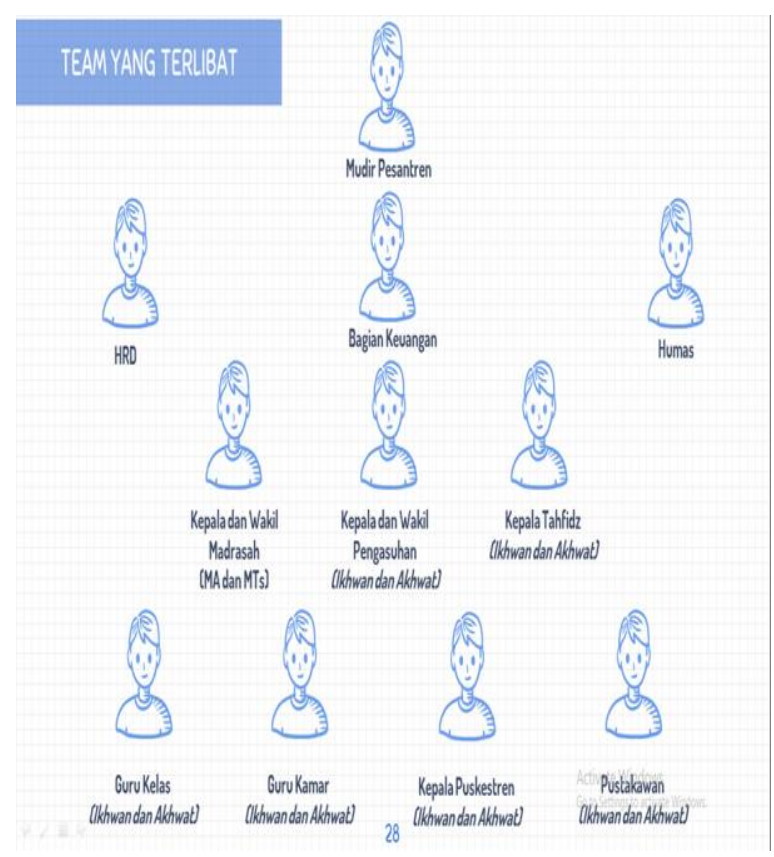

D. Metode Analisis Pengembangan Sistem Informasi e-Pesantren 4.0

1. Planning

Perencanaan yang melibatkan seluruh bagian dengan tujuan dan fungsi yang sama sehingga apa yang dikembangakn sesuai dengan kebutuhan bersama. Menganalisis sistem yang lama sehingga paham ke arah mana pengembangan sistem yang baru akan berjalan.

2. Requirements analysis

Analisis kebutuhan dalam pengembangan Sisfo e-Pesantren 4.0 yang meliputi kebutuhan dari perangkat keras, perangkat lunak, pengumpulan data yang berkait dengan pengembangan e-Peantren 4.0 dan lainya.

3. Implementation

Meletakkan sistem supaya siap dioperasikan. Implementasi sistem juga merupakan proses mengganti atau meninggalkan sistem yang lama dengan mengganti sistem yang baru. Untuk menggantikan sistem yang lama ke sistem yang baru diperlukan suatu pendekatan atau strategi supaya berhasil.

4. Desaining

Penjabaran sebuah sistem yang akan dikembangkan melalui media alur, diagram, sketsa, flowchart, dll dapat memberikan gambaran rancang bangun (blue print) yang lengkap, sebagai penuntun (guideline) bagi programmer dalam membuat aplikasi.

5. Cost Analysis

Analisis biaya merupakan analisis kebutuhan yang berkaitan dengan biaya mulai dari pembuatan, pembelian, penyewaan dll. Ini adalah bagian terpenting dalam sebuah pembanguanan sistem, tanpa adanya cost yang memadai untuk pengembangan sistem maka sistem yang akan dikebangkan juga tidak akan sesuai dengan rencana dan harapan .

6. Testing

Tahap ini, end-user yang terpilih melakukan testing terhadap fungsi-fungsi aplikasi dan melaporkan permasalahan yang ditemukan. Testing yang dilakukan merupakan simulasi penggunaan nyata dari aplikasi pada lingkungan yang sebenarnya. Proses ini merupakan tahap final sebelum pengguna menyetujui dan menerima penerapan sistem yang baru.

7. Maintenance

Tahap pemeliharaan dilakukan setelah tahap implementasi. Sistem baru yang berjalan digunakan sesuai dengan keperluan organisasi. Selama masa hidupnya, sistem secara periodik akan ditinjau. Perubahan dilakukan jika muncul masalah atau jika ternyata ada kebutuhan baru. Selanjutnya, organisasi akan menggunakan sistem yang telah diperbaiki tersebut.

\section{SIMPULAN DAN SARAN}

\section{A. Simpulan}

Dengan adanya Sistem Informasi berbasis digital E-Pesantren di Pondok Pesantren, pengurus pondok dapat mengetahui data Santri, rekap pembayaran, kurikulum dan data gedung yang dimiliki oleh pondok pesantren, hal ini berkaitan dengan pengembangan teknologi di pondok pesantren, untuk mewujudkan integrasi data santri. Aplikasi Sistem Informasi Pondok Pesantren dibuat untuk mempermudah pengelolaan informasi yang dihasilkan dari kegiatan belajar mengajar di dalam ruang lingkup Pondok Pesantren Minhajul Haq Purwakarta. Aplikasi dibuat pada platform digital agar mudah diakses dan menjangkau berbagai macam perangkat dan tidak terbatas hanya menggunakan komputer. 


\section{B. Saran}

Penelitian ini merupakan kajian awal tentang Sistem Informasi berbasis digital EPesantren di Pondok Pesantren, sehingga diperlukan adanya tindak lanjut yang lebih mendalam dalam membahas landasan teori dan praktik dalam Sistem Informasi berbasis digital E-Pesantren di Pondok Pesantren. Pada penelitian berikutnya bisa menggunakan penelitian studi kepustakaan mengenai landasan teori dan praktik Sistem Informasi berbasis digital E-Pesantren di Pondok Pesantren ini dengan membuat penelitian pengembangan ataupun penerapan dengan rujukan pustaka mengenai landasan teori dan praktik Sistem Informasi berbasis digital EPesantren di Pondok Pesantren

\section{DAFTAR RUJUKAN}

Al-Fedaghi. (2011). Developing Web Applications. International Journal of Software Engineering and Its Applications., 2(5), 57-66.

Arifudin, O. (2021). Implementasi Balanced Scorecard dalam Mewujudkan Pendidikan Tinggi World Class. Edumaspul: Jurnal Pendidikan, 5(2), 767-775.

Arikuntoro, S. (2006). prosedur penelitian suatu pendekata praktik. Jakarta:Rineka Cipta.

Bahri, A. S. (2021). PENGANTAR PENELITIAN PENDIDIKAN (Sebuah Tinjauan Teori dan Praktis). Bandung : Widina Bhakti Persada.

Bairizki, A. (2021). Manajemen Perubahan. Bandung : Widina Bhakti Persada.

Irwansyah, R. (2021). Perkembangan Peserta Didik. Bandung: Widina Bhakti Persada.

Jogiyanto. (2005). Analisis dan Desain Sistem Informasi: Pendekatan Terstruktur Teori dan Praktek Aplikasi Bisnis. Yogyakarta: Andi.

Juhji. (2020). Manajemen Humas Sekolah. Bandung: Widina Bhakti Persada.
Kristanto. (2008). Perancangan Sistem Informasi. Yogyakarta: Gava Media.

Mayasari, A. (2021). Implementasi Sistem Informasi Manajemen Akademik Berbasis Teknologi Informasi dalam Meningkatkan Mutu Pelayanan Pembelajaran di SMK. JIIPJurnal Ilmiah Ilmu Pendidikan, 4(5), 340345. https://doi.org/10.54371/jiip.v4i5.277

Nadeak, B. (2020). Manajemen Humas Pada Lembaga Pendidikan. Bandung: Widina Bhakti Persada.

Nasser, A. A. (2021). Sistem Penerimaan Siswa Baru Berbasis Web Dalam Meningkatkan Mutu Siswa Di Era Pandemi. Biormatika: Jurnal Ilmiah Fakultas Keguruan Dan Ilmu Pendidikan, 7(1), 100-109.

Rahayu, Y. N. (2020). PROGRAM LINIER (TEORI DAN APLIKASI). Bandung: Widina Bhakti Persada.

Sofyan, Y. (2020). Peranan Konseling Dosen Wali Dalam Meningkatkan Motivasi Belajar Mahasiswa Di Perguruan Tinggi Swasta Wilayah LLDIKTI IV. Jurnal Bimbingan Dan Konseling Islam, 10(2), 237-242.

Sugiyono. (2012). Metode penelitian pendidikan. Bandung:Alfabeta.

Sugiyono. (2015). Metode Penelitian Pendidikan (Pendekatan Kuantitatif,. Kualitatif dan $R \& D)$. Bandung : CV. Alfabeta.

Supriyanto. (2005). Pengantar Teknologi Informasi. Jakarta: Salemba Empat.

Syafe'i. (2017). PONDOK PESANTREN: Lembaga Pendidikan Pembentukan Karakter. AlTadzkiyyah: Jurnal Pendidikan Islam, 8(5), 85-96. 